Max-Planck-Institut für demografische Forschung

Max Planck Institute for Demographic Research

Doberaner Strasse $114 \cdot$ D-18057 Rostock - GERMANY

Tel +49 (0) 3812081 - 0; Fax +49 (0) 3812081 - 202;

http://www.demogr.mpg.de

MPIDR WORKING PAPER WP 2002-022

MAY 2002

\title{
The Role of Income \\ in Marriage and Divorce Transitions among Young Americans
}

\author{
Simon Burgess (simon.burgess@bristol.ac.uk) \\ Carol Propper (carol.propper@bristol.ac.uk) \\ Arnstein Aassve (aassve@demogr.mpg.de)
}

This working paper has been approved for release by: Francesco C. Billari (billari@demogr.mpg.de) Head of the Research Group on the Demography of Early Adulthood.

(c) Copyright is held by the authors.

Working papers of the Max Planck Institute for Demographic Research receive only limited review. Views or opinions expressed in working papers are attributable to the authors and do not necessarily reflect those of the Institute. 


\title{
The Role of Income in Marriage and Divorce Transitions among Young Americans
}

\author{
Simon Burgess+ $\quad$ Carol Propper+ \\ Arnstein Aassve* \\ +Department of Economics University of Bristol \\ Department of Economics University of Leicester
}

8 Woodland Road Bristol BS8 1TN UK.

e-mail: Simon.Burgess@bristol.ac.uk

Carol.Propper@bristol.ac.uk

April 3, 2002 


\begin{abstract}
The paper investigates the importance of income in young Americans' decisions to form and dissolve households. Using data on young American men and women from the NLSY, an important role for income in both these transitions is found. There are significant differences between young men and women. High earnings capacity increases the probability of marriage and decreases the probability of divorce for young men. High earnings capacity decreases the probability of marriage for young women, and has no impact on divorce.
\end{abstract}

JEL classification: J12 


\section{$1 \quad$ Introduction $^{1}$}

There have been large changes in household demography in the US in the last three decades. Age at marriage, rates of non-marriage, and marital disruption have all risen. Many of these changes are driven by the behaviour of young individuals. Leaving the parental home is concentrated amongst 18 to 21 year olds (Goldscheider and DaVanzo [10]) and marriage rates are highest amongst women in their mid 20s, men in their late 20s. Cohabitation is an increasingly common form of union, and is both a precursor to marriage and a substitute, the latter particularly amongst black men and women (Lillard et al [17]). Divorce rates are disproportionately concentrated amongst young adults (defined as 18-30 year olds): young men are 15 percent of the male married population but account for 32 percent of the divorces, young women are 20 percent of the female married population but account for 42 percent of the divorces (Rindfuss[25]).

There is a growing interest in the impact of economic factors on these household transitions. Economic theories of marriage imply a strong correlation between returns in the labour market and returns from the marriage market, measured in terms of the utility from marriage. For example, Becker ([3]) argued that gains from marriage are derived from the specialisation of labour within marriage, which will depend on the ratio of the male to female partner's labour income. Economists beginning with Becker et al ([4]) have also emphasised that marriage is the outcome of a search process, in which the probability of a match depends on both the quality of the searcher and the pool within which she is searching. One dimension of quality is (potential) earnings. The economic approach also makes clear that factors which determine the probability of marriage also determine the probability of marital dissolution. For example, if gains from marriage are greater for low wage 
women, this implies both higher marriage and lower divorce rates amongst low wage women. A large pool of available marriage partners will ${ }^{2}$ increase the probability of marriage, but conditional on a match being made, may also increase the chances of marital dissolution.

Empirical research, on the other hand, has generally examined either the probability of marital formation or the probability of marital dissolution (a recent exception is van de Klaauw [29]). Often the behaviour of men and women are examined separately. Comparison of results is restricted by the fact that different data sets have been used to examine men and women, and marriage formation and dissolution. The findings on the impact of economic factors are rather mixed. Most research finds a positive relationship between male earnings ability and the probability of marriage and a negative one between male earnings ability and the probability of marital dissolution. But the evidence on the relationship between female earnings ability and marriage formation is less clear ${ }^{3}$.

In this paper, we examine both marriage and divorce for both men and women. Marriage and divorce can be thought of as the outcome of a search process in which individuals are forward looking and make decisions about their living arrangements on the basis of present and future benefits and costs. We argue that an individual's own earnings ability has two effects: first, it provides an outside option (the 'self-reliance' effect), making partnership less likely; second as an indicator of quality, it raises the marriage offer rate (the 'good catch' effect), making marriage more likely. The other income available within a particular household state raises the value of staying in that state.

We estimate transitions to first marriage and dissolution of first marriage ${ }^{4}$ using a single data set. We use the National Longitudinal Survey of Youth (NLSY) from 1979 to 1992, which permits consistent definitions of the vari- 
ables of interest across the two processes. In addition, the sample is of a younger cohort than that studied by many other researchers, and so has relevance for current trends in household formation and dissolution.

We distinguish between the current and the long run potential income of the respondent, and include measures of the income of the potential or actual partner of the respondent. We find potential income in both the present state and potential other states plays an important role in both transitions. We also find significant, and consistent, gender differences in the response of household formation and dissolution to income. High potential labour income of men increases the chances of marriage and decreases the chance of dissolution. In contrast, high potential labour income of women decreases the chances of marriage and has no robust effect on the chance of dissolution. In finding this consistent gender difference, our results extend the recent empirical findings of papers which take a more structural approach ${ }^{5}$ whilst imposing fewer assumptions than required by a more structural model.

The paper is organised as follows. In Section 2 we review relevant empirical evidence. In Section 3 we outline a common framework for modelling individual choice of household type. The data are described in Section 4. The statistical model and empirical results presented in Section 5. Section 6 concludes.

\section{Empirical evidence}

There is now a very considerable literature on the economics of household formation and dissolution. We do not attempt a survey of this field but focus our attention on recent evidence on the impact of economic factors on marriage and divorce. For marriage, several papers find that economic 
independence hastens marriage for women. McLaughlin et al [21] use the NLSY for 1979-86 and find both female earnings and hours worked have a significant positive impact on the transition to marriage. Lichter et al [16] find women who live away from home and who work get married more quickly. Buck and Scott [6] using PSID data find working women have higher probability of marriage. On the other hand, van de Klaauw [29] using PSID data finds that gains to marriage are decreasing in the female wage rate $^{6}$. In one of the fewer studies that examine men's transitions to marriage, Lloyd and South [19] find that own earnings facilitate marriage.

Recently, there has been considerable focus on the impact on transitions to marriage of the marriage market and the quality of the potential partner. Most of this has examined women. South and Lloyd [26] and McLaughlin et $a l[21]$ find the availability of marriage partners (i.e. a measure of quantity of partners) for women to be a key determinant of the decision to marry. Lichter et al [16] find evidence that a shortage in both the quality and quantity of available men in local areas depresses women's transitions to first marriage, a finding confirmed by Wood [32] and Brien [5], though the latter finds that measurement error can mask the estimated impact. In an examination of male transitions to marriage, Lloyd and South [19] find a shortage in the quantity of available women, and women's aggregate independence, in the local marriage market diminishes men's marriage propensities.

The empirical evidence generally supports a negative relationship between male labour income and divorce. South and Spitze[27] find husband's hours are negatively associated with dissolution. Hoffman and Duncan [12] using data from the PSID, find the probability of divorce is lower for marriages in which the husband's labour income is higher. Weiss and Willis [33] using NLS data find positive surprises in husband's earnings decrease the probability of 
dissolution. Lillard and Waite [18] using PSID data find household income in the lowest quartile of the income distribution to be positively associated with dissolution, though they do not distinguish between the earnings of the two spouses.

Peters [24] finds significant evidence of the importance of financial considerations in the probability of divorce for women. The evidence on the relationship between female labour income and divorce is more mixed. South and Spitze[27], Spitze and South[28], Greenstein [11] find a positive relationship between hours of female employment and marital instability. Duncan and Hoffman [1] examine the characteristics of divorced women remarrying. Greenstein [11] and van De Klaauw [29] find a positive relationship between female labour income and marital instability. Weiss and Willis [33] find a positive relationship between female labour income surprises and marital instability, and a positive effect on the probability of divorce from the interaction of positive female earnings surprises and negative male income surprises. On the other hand, in a paper which focuses on the role of income, Hoffman and Duncan [12] find no support for the hypothesis that rising women's wages have increased marital instability.

\section{The role of income in household formation and dissolution}

Household formation and dissolution events involve both individual and joint decisions. Marriage requires a joint agreement, whereas divorce can be an individual decision. Marriage has been modelled as the outcome of a search process and recently theorists have explicitly modelled this as a pairwise matching process between heterogenous agents. Burdett and Coles [7] set 
out an equilibrium model of matching that includes the impact of one individual's decisions on the matching probabilities of other market participants ${ }^{7}$. Bargaining within marriage has also been modelled - this influences the division of the rent within the relationship, and hence the likelihood of the match dissolving (see Lundberg and Pollak [20]). Matching models have been useful in generating testable hypotheses as to the impact of quality on marriage rates and the size of 'marriage pools' (e.g. Lichter et al [16]). We use the general framework of a matching model to understand the impact of income within and outside the household on the probabilities of household transition behaviour.

We define three states: living with a partner ("Married"), and living in the parental home ("Home"), and living independently ("Alone"), which may include the respondent living with children or other adults, but not with a partner. The per-period utilities associated with these states are:

$$
\begin{gathered}
U^{H}=U^{H}\left(\lambda^{H} y, y_{f}, Z_{H}\right) \\
U^{A}=U^{A}\left(y, A F D C, Z_{A}\right) \\
U^{M}=U^{M}\left(\lambda^{M} y, y_{s}, Z_{M}\right)
\end{gathered}
$$

where $y$ is the respondent's earning potential, $\lambda^{j}$ represents the optimised fraction of that potential she chooses to fulfil in state $j\left(\lambda^{A}\right.$ is normalised to unity), $y_{f}$ is the income of the rest of the parental household, $y_{s}$ is the partner's income, AFDC is the generosity of the potential receipt of welfare benefits, and $Z_{j}$ are vectors of other state-specific influences on utility (these may contain variables in common). The role of $\lambda^{j}$ is to acknowledge that 
individuals will in general adjust their labour market behaviour on changing state. Earnings potential we see as primarily being determined by the standard human capital variables such as work experience and education.

\subsection{The role of own income}

The decision to live independently can be taken unilaterally by the individual: it is always an option, whether the individual currently has an offer of partnership or not. High earnings potential raises the value of this outside option $U^{A}$ and therefore, other things equal, makes transitions into the state of independent living more likely. This is the first effect of income on household formation, one we refer to as the self-reliance effect.

The value of living in a partnership depends among other things on the income of the partner. It is also depends on the division of household income between the partners: this is where a structural model of bargaining comes in. However, assuming that there is some sharing within marriage, it seems likely that a higher income partner will yield a better outcome for the respondent, other things equal. This assumption of, at least partial, income pooling implies that high income individuals will be desirable partners, and will therefore stand a higher chance of receiving offers of marriage. This provides the link to the second effect of the respondent's earnings potential on household formation.

Search theory proceeds by defining the value function for each state, deriving from these the state-specific reservation quality of a match (marriage) and expressing the transition probabilities between states in terms of the reservation values and offer arrival rates. We simply set out the main components of this approach here (see Burgess, Propper and Aassve [8] for more details). We assume a forward looking individual who seeks to maximise the 
expected present value of utility. In each state, she will with some probability receive an offer of marriage. She will accept this offer if the quality of the match is greater than her reservation quality. We assume 'quality' can be summarised as a one-dimensional attribute and that income is a measure of this. The optimal (state-specific) reservation quality is a match quality such that the individual is just indifferent between accepting the match and rejecting it. In general, the reservation level will depend on all the parameters of the search problem, including the marriage offer probability. A higher offer probability leads to a higher reservation quality: individuals receiving a lot of offers can afford to be more choosy and reject a higher fraction of offers. Under the standard assumptions, this offsetting effect is not complete and we still expect individuals with high marriage offer rates to become married somewhat sooner than individuals with low offer probabilities. This is the good catch effect: high earnings potential individuals will receive more marriage offers, and though they will raise their acceptance level accordingly, they will on this basis have a higher transition rate into marriage. This is likely to be the case under most bargaining arrangements within a marriage. Though a high earning individual might get much of the rent from marrying a low income individual, it would be an extreme case for her to get it all ${ }^{8}$; hence a low earning individual would still prefer to marry a high earning individual.

Note that the self-reliance effect (alternatives to marriage are better for high income individuals) and the good catch effect (high marriage offer rates for high income individuals) have opposite implications for the impact of own income on transitions into and out of marriage. 


\subsection{The role of other income sources}

A second important determinant of the optimum acceptance level is the distribution of quality facing the respondent. The individual will reduce her reservation level in response to a low mean quality. Again under standard assumptions, the lower the quality of potential partners, the lower the probability of marriage ${ }^{9}$.

Like an employment contract, a marriage or partnership 'contract' is agreed to by both parties but can be ended by either party. As we note above, structural models of matching markets and of bargaining address the fact that the respondent, the potential partners and later an actual partner are all making the decisions outlined above. Transitions reflect the equilibrium of this process. The probability of the individual being left by her partner depends on the behaviour of the partner, and so in turn on the partner's offer rate and reservation value, and hence on her quality and that of the respondent. In our reduced form model, the separation probability will be a function of the determinants of the offer rate, the other determinants of the reservation quality, and the costs of divorce.

Once in a match, the ambiguous effect of the respondent's own income on transitions remains: the self-reliance and good catch effect ${ }^{10}$ still matter. The same applies to the effect of the partner's income: a high earning partner might also mean either a higher or lower chance of divorce. On the other hand, income from other sources (potential alimony (rare for this young cohort), welfare payments) will increase the probability of divorce. Income of potential new partners is also a determinant of the quality of outside offers. Holding the individual's current partner's income constant, a poorer quality distribution in general means fewer acceptable offers, and hence less divorce. Thus a distribution of potential new partners with low incomes will mean a 
lower divorce rate (as noted above, it will also mean less marriage).

Income from other sources which are conditional on living alone (e.g. many welfare payments) increases income outside marriage and so decreases the likelihood of both marriage and increases the probability of divorce.

To summarise, the search approach provides the following general insights. First, the reservation quality in each origin state depends on all the parameters of the model. Second, transition rates depend upon the probability of being made an offer, the reservation quality and the distribution of the quality. Third, the decisions of a forward looking individual as to one event, say getting married, will be affected by the value and probabilities she attaches to the other events which may follow from getting married. The result is that estimation of the transition rates will depend on all the parameters which affect reservation quality and so the transition rates of one process may depend upon variables which affect another process. Turning specifically to the role of income, the effect of a high value of the respondent's own income on transition rates into and out of marriage is ambiguous. The effects of high partner's income on partnership dissolution is similarly ambiguous. High welfare payments available to those living alone will raise transitions into that state and so decrease marriage and increase divorce. A high mean quality of (other) partners will tend to raise transitions out of the current state, whether that be from living alone to form a partnership, or leaving the present partnership in the hope of forming a new one. 


\section{The data and model specification}

\subsection{The data}

We estimate transitions into and out of first marriage using data from the National Longitudinal Survey of Youth (NLSY). This is a panel data set of 12,686 persons aged between 14 and 22 years of age when first interviewed in 1979. These respondents have been reinterviewed annually ${ }^{11}$. We use data from 1979 up to and including 1992. We use observations of individuals who were in the civilian sample in $1979^{12}$. We use legal marriage as our definition of partnership.

Our sample selection decisions are as follows. We examine here white women and white men ${ }^{13}$. Individuals in the marriage sample were over 18 at the start of the survey (1979) and in the parental home at that date. Both restrictions follow from our focus on the role of own and family income. Earnings for individuals below school leaving age are likely to be very unreliable estimates of true earnings potential, and we do not know parental income for individuals who are not observed living at home in the first year of the survey. The result of these decisions is a sample of 1413 women and 1564 men at risk of forming a first marriage. Individuals in the marital dissolution sample were over 18 at the start of the survey and in a legal marriage. The dissolution date of this marriage is the date of separation or divorce (whichever is sooner). This gives a sample of 1559 women and 1116 men at risk of dissolution of this first marriage.

The data are in discrete-time event-history format. While the NLSY records the exact dates of marriage and divorce, the other variables we use are annual observations. For the estimation of time to marriage, each year of not being married is a distinct observation, beginning with 1979 and concluding 
with a partnership formation or the end of the observation period in 1992. For the estimation of time to marital dissolution, each year of marriage is a distinct observation, beginning with the first year of marriage and concluding with a dissolution or the end of the observation period in $1992^{14}$.

Table 1 gives the proportion surviving in each of the two 'at risk' groups at different durations. For marriage, the table shows that women transit into marriage more quickly than men: by age $26,45 \%$ of women remain unmarried, compared to $57 \%$ of men. For divorce, the unit is a partnership, so we would not expect to see large divergences in the separation hazards of men and women. After 7 years of marriage $85.4 \%$ of women and $85.7 \%$ of men remain married.

\subsection{Estimation methods}

Two analytic techniques were used: estimation of a proportional hazards model with a non parametric baseline hazard

$$
h(t)=h_{0}(t) e^{\beta^{\prime} x_{t}}
$$

and logistic hazard with a piecewise constant baseline hazard

$$
h(t)=1 /\left(1+\exp \left(-\theta(t)-\beta^{\prime} x_{t}\right)\right)
$$

where the dependent variable has value 1 in the year in which the event first occurs and is 0 otherwise. (5) allows the baseline hazard to vary over time in a flexible way and allows identification of duration effects. It is commonly used in duration modelling (Jenkins [13]). Our empirical results using (4) and (5) are similar so only the second set of estimates are presented below.We do not take into account unobserved heterogeneity in our estimation, but we 
do include a large number of observed covariates. In addition, failure to take into account unobserved heterogeneity is less likely to bias our estimates because we have modelled the baseline hazard very flexibly[9].

\subsection{The covariates}

Our focus is on the impact of income on the timing of transitions into and out of marriage. Under the theoretical model sketched above, state transitions are influenced by the earnings potential of the individual. For estimation purposes, we define four measures of the earnings potential of the respondent. The first is real annual earnings (Current earnings). Although annual income is widely used in empirical work on marriage, in a young sample annual earnings may be a poor measure of earnings capacity. Some individuals just beginning work may have low current earnings but high long run earnings because they are receiving on the job training. Alternatively, those with initially high relative earnings may be in jobs in which they have little opportunity to improve their skills, so have lower long run earnings.

To correct for the potentially large size of the transitory component of income we constructed a measure of long run earnings ability (Long run earnings). One possible measure of this would be the average earnings of the individual whilst they are in the 'at-risk' sample. However, in an investigation of the impact of income of household formation, this measure would be misleading. Earnings grow rapidly with age in this young sample, so individuals who leave the sample early have low earnings. By using the average whilst 'at-risk' we would create an automatic correlation of long run earnings and the probability of marriage, and to a lesser extent, a similar correlation with the probability of dissolution. We therefore used instead, as a measure of long run earnings potential, the individual's estimated fixed effect from 
a panel regression of real earnings on work experience for the whole period 1979-92. To take account of events which disrupt the link between age, earnings and experience we condition on the number of children of the respondent and the local unemployment rate.

One issue is the potential endogeneity of earnings for marriage transitions. It may be that changes in marital status cause changes in earnings (see Koremann and Neumark [15]). Our use of the long run fixed effects variable helps to reduce this problem. That is, year-to-year changes in income are stripped out, so this variable addresses the question of whether individuals who have high earnings on average have different marriage and divorce profiles than individuals who are on average low earners. The regression from which the fixed effects are generated is given in Appendix Table A1.

However, it can be argued that even this long run earnings measure does not overcome the problem of potential reverse causality. For example, if women who expect to become divorced work longer hours as a method of self insurance (e.g. Johnson and Skinner 1986 [14]), then high income will be associated with divorce. But the direction of causation is reversed from the case where high earning women divorce because of the 'self-reliance' effect considered here. We therefore estimate a long run fixed effects measure of wage rates (earnings per hour, labelled in tables Long run wage rate), derived in the same manner as our estimate of long run fixed effect of income. (The estimates are in Table A1). For completeness, we report results using current wage rates (Current wage rate), which might be argued to be less endogenous than current income. In summary, we view measures of wage rates as more exogenous than measures of earnings, and long run wages as the most exogenous measure of potential income.

Using measures based on the entire sample history is one way of dealing 
with the identification issue that arises from simultaneous changes in income and marital status. The use of such measures does not deal with the possibility that high lifetime earnings or wages may be correlated with a taste for marriage. We attempt to deal with this by controlling for a relatively large set of background variables (listed below) that relate to income and living arrangements when the respondent was young. Finally, note that these are all measures of the level of earnings, not unexpected surprises as in Weiss and Willis [33]..$^{15}$

We construct the following measure of the quality of the potential marriage partners (Mean Quality Offer). For an individual of a given age, race, education level and region of residence ${ }^{16}$, Mean Quality Offer is the mean real wage rate of individuals in the NLSY of the opposite gender, same race, education and region of residence, and an age difference of two years ${ }^{17}$. That is, we calculate the mean real wage rate for age $\backslash$ gender $\backslash$ education group \region \year cells for whites. In contrast to measures used in some studies, it is not a measure of the availability of potential partners but a measure of the average quality of the potential partners. This is used in estimation of both the marital formation and dissolution probability ${ }^{18}$. In the dissolution equation we also require a measure of resources within the household. We use the real income of the household of the respondent excluding that of the respondent (Income of spouse). All income variables for the respondent and, where relevant, of their spouse, are real and are lagged one year to reduce the problem of endogeneity.

As the final measure of resources potentially available to the respondent, we construct a measure of the income the respondent would have access to if they were on welfare. As the impact of welfare payments is not the primary focus of this paper, we construct a categorical measure of the relative 
generosity of welfare payments to single parents with children (AFDC), which varies between 1 and 6 between states.

The risk of the transitions were adjusted for other covariates. First, we control for the ability of the respondent to generate income. NLSY respondents completed AFQT tests at first interview. As a measure of ability we use AFQT score in 1979, relative to the mean score for individuals of their age in 1979. For the same reason we also control for family income of the respondent in 1978 and interact this with the age of the respondent in $1979^{19}$. Second, we include a number of background controls to account for some of the heterogeneity. These controls measure the type of family the respondent grew up in and their attitudes towards family life and gender roles (whether they lived with both parents at age 14, whether the respondent had a religious upbringing ${ }^{20}$, the number of siblings, parental education, parental work status in 1978, and a measure of the respondent's belief in traditional gender roles in 1979). State dummies are also included.

Third, in the dissolution equation we control for observed measures of match quality (the respondent's age at marriage ${ }^{21}$, the number of children, whether any children are under 6 , whether the respondent had a premarital birth $)^{22}$. Fourth, in both the marriage and dissolution equations we include the county divorce rate. This is a reduced form control which may pick up differences in the cost of getting divorced. Previous research has focused on the impact of costs of divorce in the dissolution hazard (e.g. Waite and Lillard [30]). However, the search theoretical framework makes it clear that factors that affect the probability of divorce will also affect the probability of marriage. Finally, we allow flexibly for duration effects in both hazards (splines in age since 13 in the marriage hazard, and years of duration of marriage in the dissolution hazard). 


\section{Results}

\subsection{Time to Marriage}

We estimate time to marriage using the full set of background variables and the four different measures of income. Table 2 presents the estimates for men and Table 3 for women. The tables focus on the impact of the economic variables: estimates of all parameters are given in the Appendix.

The results for men indicate that high own income reduces the time to marriage. The estimated coefficients on all measures of earnings ability are positive and well defined. The impact of the long run measures is higher than that of the current measures. This might reflect the fact that current income is a noisier measure of potential income, or it may indicate that high transitory income has less of an impact than high long run income. The impact of income of others (parental income) is to delay marriage. But this impact tails off with age: the net impact of high family income at age 20 is close to zero. The impact of the 'marriage market' variables - the mean quality of the potential spouse, the county divorce rate and the generosity of the benefit system for single mothers with children - is small in magnitude and the estimates are almost all not significantly different from zero.

The results for women are somewhat different. The estimated impact of current earnings is positive, but the estimated impacts of all other measures of own resources are to delay marriage, and these estimates are significantly different from zero for current wages and long run income. These results suggest that the effect of current earnings for young women is misleading. This is not surprising given that, in a sample of young women hours of work, schooling, and living arrangements may be jointly determined. Using less endogenous measures, it appears the effect of own income for women is to 
delay marriage. The effect of the income of others (parental income) is to delay marriage (as for men) although (as for men) there is some tailing off of the impact with age. The marriage market variables appear to have more impact for women than for men. AFDC generosity and the county divorce rate are both positively associated with time to marriage for women and, in some cases, these coefficients are well defined. Personal receipt of AFDC is not, however, significantly associated with time to marriage for women. The mean quality of the potential spouse is generally negatively associated with time to marriage, which is of opposite sign to that expected.

These results were subject to a number of tests for robustness. First, individuals who are young may be undertaking a number of activities, some to do with education and the labour market, and others to do with finding a partner. Our paper focuses on the impact of resources on the latter, but it is possible that the link we find between marriage and resources may be due to the link between resources and these other activities. To examine this, we re-estimated time to marriage conditional on current living arrangements and current educational status. Given that we already use a rich set of background variables, including parental education and living arrangements at 14, we are not able to find convincing instruments for these variables, so we simply re-estimated conditioning on whether the individual is living independently from their parents and whether or not the individual is enrolled in college. Conditioning on living independently from parents and being enrolled at college reduces the absolute value of the income coefficients. On the other hand, conditioning on a pre-marital birth, which might be expected also to be correlated with similar factors, has no impact on the income estimates.

Second, the results are also robust to re-estimation on a larger sample in which cohabitations are included as well as legal marriages. Inclusion of 
cohabiting individuals does not change the estimates of the effect of own or parental resources for either men or women.

\subsection{Time to dissolution}

The results for time to dissolution of first marriage are presented in Tables 4 (men) and 5 (women). Table 4 shows that own resources for men are associated with slower time to dissolution. All the measures of potential income have negative coefficient estimates, although two of the estimated coefficients are not significant at conventional levels. Spouse's income significantly delays exit from marriage. The impact of the marriage market variables - quality of potential partner, county divorce rate and AFDC generosity - are all small and not significantly different from zero. The effects of most of the measures of marriage specific capital - number of children, having any children, and having children under 6 - are not well defined, but having a pre-marital birth is significantly associated with faster dissolution. Time to marriage is associated with slower time to dissolution: those who marry later are less likely to get divorced within the sample window.

The results for women are slightly different. The two measures of own earnings are positively associated with time to dissolution, indicating that high earning women exit marriages faster. On the other hand, the two measures of wages are not associated with time to dissolution, suggesting that the more exogenous measures of earnings potential are not significantly associated with time to dissolution. The difference in patterns may be explained by endogeneity: women who anticipate marital dissolution may 'self insure' by working more hours, and thus the coefficients on earnings are upwardly biased. The impact of spouse's income is, as for men, to delay exit from marriage, but while the sign is the same for both men and women, the estimated 
size of the effect of spouse's income for women is about twice that for men.

The impact of the marriage market variable, quality of potential partner, is negative (i.e. of the wrong sign) though not well defined. As for men, there is no significant impact of the county divorce rate. AFDC generosity appears to delay exit from marriage, but the coefficients are not well defined. The effects of measures of marriage specific capital - number of children, having any children, and having children under 6 - are not well defined, but these estimates are generally negative (as for men). Having a pre-marital birth is associated with faster dissolution. Time to marriage is associated with slower time to dissolution. The coefficients on these last two variables are of similar magnitude for the two genders.

These results were also subject to a number of tests for robustness (the results are available from the authors). First, the results presented in tables 4 and 5 use spouse's income as a measure of the resources of the spouse. The results were re-estimated using wage rates instead of income. The coefficient estimates did not change significantly. Second, the results were re-estimated on the sample which included individuals in cohabiting partnerships. As for the analysis of partnership formation, the estimates change little when the extra observations are added to the sample.

\subsection{Discussion}

Taking all the income measures as a whole, our results indicate gender differences in the impact of income on marriage formation and dissolution. Men with higher wage rates and earnings potential get married quicker while women with higher wage rates and earnings potential delay marriage (though the coefficient estimate on the long run wage rate measure for women is not significantly different from zero). High wage rates and earnings potential is 
negatively associated with marital dissolution for men, but has no impact (wages) or a positive impact (earnings) for women. This suggests that, for men, the main impact of higher income is the 'good catch' effect. For women, the main impact is the 'self-reliance' effect. That is, having high potential income generating ability leads women to delay marriage, whereas for men, high potential income hastens marriage and then makes a dissolution less likely. Our results also show that failure to address the endogeneity of current female earnings will give an upward bias to the estimated impact of female earnings on the transitions to marriage.

We find no difference between the genders in the impact of other income within a match. For both men and women, a higher-earning spouse reduces the hazard of dissolution. For both genders and both transitions our estimates of income in the potential alternative to the current state (the earnings ability of a potential partner and AFDC) appears to have little impact on the time to marriage or to dissolution. This may be because we use somewhat crude measures of these sources of income. But it may also reflect the fact that outside options are given less weight than current circumstances, either because of moving costs or because individuals have poor information about outside options.

With the exception of the impact of own income potential, the results indicate considerable similarity across the genders within both of the two hazards. Income of others, income from other sources and match specific capital appear to have similar effects on the behaviour of young women and men. As a dissolution is the separation of a unit containing a male and a female partner, our findings that the impact of match specific capital on the hazard of dissolution is similar for men and for women is reassuring.

In finding a gender difference in the impact of own earnings potential on 
time to marriage our research extends both earlier research and two recent studies which have taken a more structural approach, but have either only looked at one transition (Weiss and Willis [33]) or one gender (van der Klaauw [29]). This difference between genders was first suggested in the economics literature by Becker in the early 1970s. Much of the previous empirical support for this comes from the behaviour of individuals who around 10 years older than the individuals examined here. It is interesting that this difference appears to persist, despite considerable social change in attitudes and in female labour market participation.

\section{Conclusions}

In this paper we have investigated the impact of income sources on the transitions into and out of first marriage. Informed by a search theoretic framework, we argue that an individual's own earnings have two effects: first, they provide an outside option (the 'self-reliance' effect), making marriage less likely; second as an indicator of quality, they raise the marriage offer rate (the 'good catch' effect), making marriage more likely. The other income available within a particular household state raises the value of staying in that state, but the impact of this on transition rates is complicated by the fact that this other income also acts as the outside option of the partner. The net effect of inside income on transition rates is therefore also ambiguous.

Unlike most previous research, we estimate both these transitions using a single data set (the NLSY) which contains data on individuals who were aged 14-21 in 1979. We also examine both men and women. Our results suggest that for men, the 'good catch' effect dominates, whereas for women the 'self-reliance' effect is more important. High earnings potential raises the 
probability of marriage for men, but decreases it for women; high earnings potential is negatively associated with marital dissolution for men, but has no impact for women.

\section{References}

$[1]$

[2] A. Aassve. Marital dissolution among young americans: The role of income variables and past family formation behaviour. University of Bristol, Department of Economics Discussion Paper, 516, 2000.

[3] G. S. Becker. A theory of marriage: Part 1. Journal of Political Economy, 81:813-846, 1973.

[4] G. S. Becker, E. Landes, and R. Michael. An economic analysis of marital instability. Journal of Political Economy, 85:1141-1187, 1977.

[5] M. J. Brien. Racial differences in marriage and the role of marriage markets. Journal of Human Resources, 32:741-778, 1997.

[6] N. Buck and J. Scott. She's leaving home: But why? an analysis of young people leaving the parental home. Journal of Marriage and the Family, 55:863-874, November 1993.

[7] K. Burdett and M. Coles. Matching and dynamics. mimeo, University of Essex.

[8] S. Burgess, C. Propper, and A. Aassve. Incomes and the transitions to independent living, marriage and divorce among young americans. mimeo, Department of Economics University of Bristol, 1997. 
[9] P. J. Dolton and W. van der Klaauw. Leaving teaching in the uk: A duration analysis. Economic Journal, 105:431-444, 1995.

[10] F. K. Goldscheider and J. DaVanzo. Living arrangements and the transition to adulthood. Demography, 22:545-563, November 1985.

[11] T. Greenstein. Marital disruption and the employment of married women. Journal of Marriage and the Family, 52:657-676, 1990.

[12] S. Hoffman and G. Duncan. The effect of incomes, wages and afdc benefits on marital disruption. Journal of Human Resources, 30:19-41, 1997.

[13] S. P. Jenkins. Easy estimation methods for discrete-time duration models. Oxford Bulletin of Economics and Statistics, 57:129-138, 1995.

[14] W. Johnson and J. Skinner. Labor supply and marital separation. American Economic Review, 76, 1986.

[15] S. J. Koremann and D. Neumark. Does marriage really make men more productive. Journal of Human Resources, 14:579-594, 1991.

[16] D. T. Lichter, D. K. McLaughlin, G. Kephart, and D. J. Landry. Race and the retreat from marriage: A shortage of marriageable men? American Sociological Review, 57:781-799, December 1992.

[17] L. A. Lillard, M. J. Brien, and L. J. Waite. Premarital cohabitation and subsequent marital dissolution: A matter of self-selection? Demography, 32:437-457, August 1995.

[18] L. A. Lillard and L. J. Waite. A joint model of marital childbearing and marital disruption. Demography, 30:653-681, November 1993. 
[19] K. M. Lloyd and S. J. South. Contextual influences on young men's transition to first marriage. Social Forces, 74, 1996.

[20] S. Lundberg and R. A. Pollack. Bargaining and distribution in a marriage. Journal of Economic Perspectives, 10(4):139-158, 1996.

[21] D. McLaughlin, D. T. Lichter, and G. M. Johnston. Some women marry young: Transition to first marriage in metropolitan and nonmetropolitan areas. Journal of Marriage and the Family, 55:827-838, November 1993.

[22] R. T. Michael and N. B. Tuma. Entry into marriage and parenthood by young men and women: The influence of family background. Demography, 22:515-543, November 1985.

[23] R. Moffitt. The effect of the u.s. welfare system on marital status. Journal of Public Economics, pages 101-124, 1990.

[24] H. E. Peters. The importance of financial conisderations in divorce decisions. Economic Inquiry, 31:71-86, 1993.

[25] R. D. Rindfuss. The young adult years: Diversity, structural change, and fertility. Demography, 28:493-512, November 1991.

[26] S. South and K. Lloyd. Marriage opportunities and family formation: Further implications of imbalanced sex ratios. Journal of Marriage and the Family, 54:440-451, 1992.

[27] S. J. South and G. Spitze. Determinants of divorce over the marital life course. American Sociological Review, 51:583-590, August 1986.

[28] G. Spitze and S. South. Women's employment, time expenditure, and divorce. Journal of Family Issues, 12:181-196, 1985. 
[29] W. van der Klaauw. Female labour supply and mairal status decisions: A life-cycle model. Review of Economic Studies, 63:119-235, 1996.

[30] L. J. Waite and L. A. Lillard. Children and marital disruption. American Journal of Sociology, 96:930-953, January 1991.

[31] T. Webb. Marriage and divorce. University of Bristol Department of Economics Disc. Paper, (483), 2000.

[32] R. G. Wood. Marriage rates and marriageable men: A test of the wilson hypothesis. Journal of Human Resources, 30, 1995.

[33] W. Y. and R. J. Willis. Match quality, new information, and marital dissolution. Journal of Labor Economics, 15:S293-S329, 1997.

\section{Notes}

${ }^{1}$ Thanks are due to seminar audiences at Bristol and the Royal Economic Society, two anonymous referees and the Editor for useful comments, and to Matt Dickson for preparation of the tables. Any errors are those of the authors.

${ }^{2}$ Under standard assumptions about behaviour of reservation wages.

${ }^{3}$ For example, Hoffman and Duncan ([12]) find increased earnings ability slows the transitions to dissolution for women, McLaughlin et al ([21]) find that working hastens transitions to marriage by women, while van de Klaauw ([29]) finds the opposite effect of his definition of earnings ability on both transitions.

${ }^{4}$ In the empirical analyses, dissolution is defined as separation or legal divorce, whichever is the earlier.

${ }^{5}$ e.g. van de Klaauw [29] and Weiss and Willis [33]

${ }^{6}$ Another source of income which is particuarly important for certain groups of women 
is AFDC. Using cross sectional (CPS) data, Moffitt [23] finds significant effects of AFDC on the probability of marriage. But these effects are stronger for men than for women, particularly for blacks.

${ }^{7}$ See also Webb [31] for an extension of this to include divorce.

${ }^{8}$ The frictions inherent in a search and matching market give the low earning individual some bargaining power.

${ }^{9}$ In an examination of marriage among black women, Lichter et al (1992) stress the first effect, arguing that the retreat from marriage amongst black women may be due to a shortage of eligible men.

${ }^{10}$ In the context of a partnership, this latter effect is best interpreted as meaning that high income individuals are valued as partners and therefore effort will be put into keeping them.

${ }^{11}$ The retention rate in 1991 was $90.5 \%$

${ }^{12}$ The NLSY took three independent probability samples designed to represent the entire population of youth in the US on January 1 1979: (a) a cross section of the relevant population (b) a supplemental sample of Hispanic, Black and economically disadvantaged whites and (c) a sample of young persons in the military. In our analysis we use both samples (a) and (b) but do not use sample weights.

${ }^{13}$ In previous versions of this paper we looked at partnerships including both marriage and cohabitation, and also report results for blacks, hispanics and whites separately (Burgess et al [8]).

${ }^{14}$ Further details of the construction of the two 'person-period' data sets are in Burgess et al [8].

${ }^{15}$ Using the NLSY, one of us (Aassve) examines the impact of income surprises on divorce [2].

${ }^{16}$ Region has 4 categories. 
${ }^{17}$ From our data, females marry males on average two years their senior, and males marry females two years their junior.

${ }^{18}$ Use of the same measure for both the hazard of marriage and of divorce is based on our assumption that the pool of available individuals is all members of the opposite sex (suitably adjusted for race, education and location).

${ }^{19}$ As all the 'at risk of marrriage' sample were living in the parental home in 1979 , this is basically parental income.

${ }^{20}$ Religious beliefs have been shown to be important determinants of marriage (Michael and Tuma 1985 [22]) and Catholic prohibition of divorce means the costs of getting divorced are likely to be higher for Catholics than non-Catholics.

${ }^{21}$ In general, the respondent's age at marriage is likely to be endogenous in the marital dissolution equation, but ignoring this potential endogeneity is consistent with our assumption of no residual heterogeneity in the marriage equation.

${ }^{22}$ Previous research e.g. Lillard and Waite (1993), Weiss and Willis (1997), van der Klaauw (1996) has shown that children and age at marriage are determinants of match quality. 
Table 1: Time to Marriage and Divorce: Unconditional Hazards

Time to Marriage

\begin{tabular}{ccc}
\hline Age & Women & \multicolumn{1}{l}{ Men } \\
& & \\
\hline & & \\
18 & 0.958 & 0.991 \\
20 & 0.836 & 0.934 \\
22 & 0.685 & 0.818 \\
24 & 0.546 & 0.681 \\
26 & 0.445 & 0.573 \\
28 & 0.395 & 0.517 \\
30 & 0.327 & 0.427 \\
32 & 0.264 & 0.332 \\
34 & 0.193 & 0.246 \\
& & \\
& & \\
& & \\
\hline
\end{tabular}

Proportion remaining unmarried by the indicated age
Time to Separation

\begin{tabular}{lcc}
\hline $\begin{array}{c}\text { Marriage } \\
\text { Duration } \\
\text { (years) }\end{array}$ & Women & Men \\
\hline & & \\
1 & 0.991 & 0.984 \\
2 & 0.969 & 0.967 \\
3 & 0.946 & 0.943 \\
4 & 0.918 & 0.931 \\
5 & 0.889 & 0.911 \\
6 & 0.868 & 0.874 \\
7 & 0.854 & 0.857 \\
8 & 0.839 & 0.811 \\
9 & 0.834 & 0.799 \\
10 & 0.817 & 0.782 \\
& & \\
& & \\
\hline
\end{tabular}

Proportion remaining married by the indicated duration 
Table 2: Hazard Rate Estimates of Time to Marriage, Men

\begin{tabular}{|c|c|c|c|c|}
\hline $\begin{array}{l}\text { Measure of own } \\
\text { income : }\end{array}$ & $\begin{array}{r}\text { Current } \\
\text { Earnings } \\
\end{array}$ & $\begin{array}{l}\text { Long run } \\
\text { Earnings }\end{array}$ & $\begin{array}{r}\text { Current Wage } \\
\text { Rate } \\
\end{array}$ & $\begin{array}{r}\text { Long run Wage } \\
\text { Rate } \\
\end{array}$ \\
\hline Current Earnings & $\begin{array}{r}0.00008 \\
(9.11)\end{array}$ & & & \\
\hline $\begin{array}{l}\text { Long run } \\
\text { Earnings }\end{array}$ & & $\begin{array}{l}0.020 \\
(5.19)\end{array}$ & & \\
\hline $\begin{array}{l}\text { Current Wage } \\
\text { Rate }\end{array}$ & & & $\begin{array}{r}0.007 \\
(2.26)\end{array}$ & \\
\hline $\begin{array}{l}\text { Long run Wage } \\
\text { Rate }\end{array}$ & & & & $\begin{array}{l}0.030 \\
(3.35)\end{array}$ \\
\hline $\begin{array}{l}\text { Family Income in } \\
1979\end{array}$ & $\begin{array}{l}-0.041 \\
(-3.12)\end{array}$ & $\begin{array}{r}-0.042 \\
(-3.27)\end{array}$ & $\begin{array}{l}-0.055 \\
(-4.48)\end{array}$ & $\begin{array}{l}-0.042 \\
(-3.25)\end{array}$ \\
\hline $\begin{array}{l}\text { Family Income in } \\
1979^{*} \text { Age }\end{array}$ & $\begin{array}{l}0.002 \\
(3.06)\end{array}$ & $\begin{array}{l}0.002 \\
(3.08)\end{array}$ & $\begin{array}{l}0.002 \\
(4.39)\end{array}$ & $\begin{array}{l}0.002 \\
(3.10)\end{array}$ \\
\hline $\begin{array}{l}\text { Mean Quality } \\
\text { Offer }\end{array}$ & $\begin{array}{l}-0.003 \\
(-0.16)\end{array}$ & $\begin{array}{l}-0.015 \\
(-0.76)\end{array}$ & $\begin{array}{l}-0.001 \\
(-0.08)\end{array}$ & $\begin{array}{c}-0.012 \\
(-0.61)\end{array}$ \\
\hline AFDC Generosity & $\begin{array}{l}-0.030 \\
(-0.41)\end{array}$ & $\begin{array}{l}0.001 \\
(0.01)\end{array}$ & $\begin{array}{l}0.012 \\
(0.19)\end{array}$ & $\begin{array}{l}-0.022 \\
(-0.31)\end{array}$ \\
\hline $\begin{array}{l}\text { County divorce } \\
\text { Rate }\end{array}$ & $\begin{array}{l}0.001 \\
(0.23)\end{array}$ & $\begin{array}{l}0.001 \\
(0.32)\end{array}$ & $\begin{array}{l}0.001 \\
(0.60)\end{array}$ & $\begin{array}{l}0.001 \\
(0.36)\end{array}$ \\
\hline \# obs : & 7263 & 7340 & 8460 & 7265 \\
\hline
\end{tabular}

\footnotetext{
Notes

Additional included variables are a set of age dummies, the individual's normalised AFQT score, a measure of the individual's adherence to traditional gender roles, state dummies, and dummies for: whether the individual has siblings, had a religious up-bringing, lived in an intact family at age 14, father was a high school drop-out, and father worked full-time at age 14.

Long run wages and long run earnings are the individual's estimated fixed effect from a fixed effect regression for wage rates and earnings respectively (see Appendix Table 1).

$\mathrm{t}$-statistics in parentheses.
} 
Table 3: Hazard Rate Estimates of Time to Marriage, Women

\begin{tabular}{|c|c|c|c|c|}
\hline $\begin{array}{l}\text { Measure of own } \\
\text { income : }\end{array}$ & $\begin{array}{r}\text { Current } \\
\text { Earnings } \\
\end{array}$ & $\begin{array}{l}\text { Long run } \\
\text { Earnings } \\
\end{array}$ & $\begin{array}{r}\text { Current Wage } \\
\text { Rate }\end{array}$ & $\begin{array}{r}\text { Long run Wage } \\
\text { Rate } \\
\end{array}$ \\
\hline Current Earnings & $\begin{array}{r}0.00005 \\
(5.58)\end{array}$ & & & \\
\hline $\begin{array}{l}\text { Long run } \\
\text { Earnings }\end{array}$ & & $\begin{array}{l}-0.029 \\
(-4.20)\end{array}$ & & \\
\hline $\begin{array}{l}\text { Current Wage } \\
\text { Rate }\end{array}$ & & & $\begin{array}{l}-0.021 \\
(-2.08)\end{array}$ & \\
\hline $\begin{array}{l}\text { Long run Wage } \\
\text { Rate }\end{array}$ & & & & $\begin{array}{l}-0.012 \\
(-0.92)\end{array}$ \\
\hline $\begin{array}{l}\text { Family Income in } \\
1979\end{array}$ & $\begin{array}{l}-0.018 \\
(-1.54)\end{array}$ & $\begin{array}{r}-0.027 \\
(-2.19)\end{array}$ & $\begin{array}{r}-0.032 \\
(-2.89)\end{array}$ & $\begin{array}{r}-0.021 \\
(-1.76)\end{array}$ \\
\hline $\begin{array}{l}\text { Family Income in } \\
1979 * \text { Age }\end{array}$ & $\begin{array}{l}0.001 \\
(1.54)\end{array}$ & $\begin{array}{l}0.001 \\
(2.18)\end{array}$ & $\begin{array}{l}0.001 \\
(2.88)\end{array}$ & $\begin{array}{l}0.001 \\
(1.75)\end{array}$ \\
\hline $\begin{array}{l}\text { Mean Quality } \\
\text { Offer }\end{array}$ & $\begin{array}{r}-0.087 \\
(2.34)\end{array}$ & $\begin{array}{l}-0.056 \\
(-1.49)\end{array}$ & $\begin{array}{l}-0.029 \\
(-0.82)\end{array}$ & $\begin{array}{l}-0.079 \\
(-2.11)\end{array}$ \\
\hline AFDC Generosity & $\begin{array}{l}0.063 \\
(0.87)\end{array}$ & $\begin{array}{l}0.081 \\
(1.13)\end{array}$ & $\begin{array}{r}0.042 \\
(0.69)\end{array}$ & $\begin{array}{l}0.080 \\
(1.10)\end{array}$ \\
\hline $\begin{array}{l}\text { County divorce } \\
\text { Rate }\end{array}$ & $\begin{array}{l}0.004 \\
(1.69)\end{array}$ & $\begin{array}{r}0.005 \\
(1.96)\end{array}$ & $\begin{array}{l}0.003 \\
(1.41)\end{array}$ & $\begin{array}{r}0.005 \\
(1.77)\end{array}$ \\
\hline AFDC Receipt & $\begin{array}{l}-0.051 \\
(-0.26)\end{array}$ & $\begin{array}{l}-0.110 \\
(-0.56)\end{array}$ & $\begin{array}{r}-0.149 \\
(-0.77)\end{array}$ & $\begin{array}{l}-0.108 \\
(-0.54)\end{array}$ \\
\hline \# obs : & 5332 & 5373 & 6421 & 5331 \\
\hline
\end{tabular}

Notes

Additional included variables are a set of age dummies, the individual's normalised AFQT score, a measure of the individual's adherence to traditional gender roles, state dummies, and dummies for: whether the individual has siblings, had a religious up-bringing, lived in an intact family at age 14, father was a high school drop-out, and father worked full-time at age 14.

Long run wages and long run earnings are the individual's estimated fixed effect from a fixed effect regression for wage rates and earnings respectively (see Appendix Table 1).

t-statistics in parentheses. 
Table 4: Hazard rate estimates of time to Divorce, Men

\begin{tabular}{|c|c|c|c|c|}
\hline $\begin{array}{l}\text { Measure of own } \\
\text { income : }\end{array}$ & $\begin{array}{r}\text { Current } \\
\text { Earnings } \\
\end{array}$ & $\begin{array}{l}\text { Long run } \\
\text { Earnings } \\
\end{array}$ & $\begin{array}{r}\text { Current Wage } \\
\text { Rate }\end{array}$ & $\begin{array}{r}\text { Long run Wage } \\
\text { Rate } \\
\end{array}$ \\
\hline Current Earnings & $\begin{array}{l}-0.020 \\
(-2.57)\end{array}$ & & & \\
\hline Long run Earnings & & $\begin{array}{l}-0.019 \\
(-1.84)\end{array}$ & & \\
\hline $\begin{array}{l}\text { Current Wage } \\
\text { Rate }\end{array}$ & & & $\begin{array}{l}-0.026 \\
(-1.59)\end{array}$ & \\
\hline $\begin{array}{l}\text { Long run Wage } \\
\text { Rate }\end{array}$ & & & & $\begin{array}{l}-0.065 \\
(-2.58)\end{array}$ \\
\hline Income of spouse & $\begin{array}{l}-0.020 \\
(-2.20)\end{array}$ & $\begin{array}{l}-0.019 \\
(-2.01)\end{array}$ & $\begin{array}{l}-0.023 \\
(-2.45)\end{array}$ & $\begin{array}{l}-0.020 \\
(-2.08)\end{array}$ \\
\hline $\begin{array}{l}\text { Mean Quality } \\
\text { Offer }\end{array}$ & $\begin{array}{l}0.014 \\
(0.37)\end{array}$ & $\begin{array}{l}-0.002 \\
(-0.04)\end{array}$ & $\begin{array}{r}0.014 \\
(0.35)\end{array}$ & $\begin{array}{l}-0.0002 \\
(-0.005)\end{array}$ \\
\hline $\begin{array}{l}\text { County divorce } \\
\text { rate }\end{array}$ & $\begin{array}{l}0.001 \\
(0.30)\end{array}$ & $\begin{array}{l}0.002 \\
(0.39)\end{array}$ & $\begin{array}{l}0.000 \\
(0.03)\end{array}$ & $\begin{array}{l}0.002 \\
(0.43)\end{array}$ \\
\hline AFDC Generosity & $\begin{array}{l}-0.064 \\
(-0.43)\end{array}$ & $\begin{array}{l}-0.104 \\
(-0.63)\end{array}$ & $\begin{array}{l}-0.060 \\
(-0.39)\end{array}$ & $\begin{array}{l}-0.092 \\
(-0.55)\end{array}$ \\
\hline Date of Marriage & $\begin{array}{l}-0.007 \\
(-2.56)\end{array}$ & $\begin{array}{l}-0.009 \\
(-3.11)\end{array}$ & $\begin{array}{l}-0.008 \\
(-2.79)\end{array}$ & $\begin{array}{l}-0.009 \\
(-3.09)\end{array}$ \\
\hline $\begin{array}{l}\text { Children under } 6 \\
\text { years old }\end{array}$ & $\begin{array}{l}-0.373 \\
(-1.27)\end{array}$ & $\begin{array}{l}-0.238 \\
(-0.75)\end{array}$ & $\begin{array}{l}-0.174 \\
(-0.56)\end{array}$ & $\begin{array}{l}-0.264 \\
(-0.83)\end{array}$ \\
\hline Pre-marital birth & $\begin{array}{l}0.733 \\
(2.24)\end{array}$ & $\begin{array}{l}0.692 \\
(1.93)\end{array}$ & $\begin{array}{l}0.759 \\
(2.20)\end{array}$ & $\begin{array}{l}0.726 \\
(2.02)\end{array}$ \\
\hline Any Birth & $\begin{array}{l}0.364 \\
(1.08)\end{array}$ & $\begin{array}{l}0.192 \\
(0.53)\end{array}$ & $\begin{array}{l}0.100 \\
(0.28)\end{array}$ & $\begin{array}{l}0.210 \\
(0.57)\end{array}$ \\
\hline Number of Births & $\begin{array}{r}-0.043 \\
(-0.30) \\
\end{array}$ & $\begin{array}{r}-0.044 \\
(-0.28) \\
\end{array}$ & $\begin{array}{r}0.001 \\
(0.01) \\
\end{array}$ & $\begin{array}{r}-0.051 \\
(-0.31) \\
\end{array}$ \\
\hline \# obs : & 6058 & 5466 & 5711 & 5447 \\
\hline
\end{tabular}

Notes

Additional included variables are a set of dummies for duration of marriage, the individual's normalised AFQT score, a measure of the individual's adherence to traditional gender roles, state dummies, and dummies for: whether the individual had a religious up-bringing, lived in an intact family at age 14, either parent was a high school drop-out, either parent worked full-time at age 14 .

Long run wages and long run earnings are the individual's estimated fixed effect from a fixed effect regression for wage rates and earnings respectively (see Appendix Table 1).

$\mathrm{t}$-statistics in parentheses. 
Table 5: Hazard rate estimates of time to Divorce, Women

\begin{tabular}{|c|c|c|c|c|}
\hline $\begin{array}{l}\text { Measure of own } \\
\text { income : }\end{array}$ & $\begin{array}{r}\text { Current } \\
\text { Earnings } \\
\end{array}$ & $\begin{array}{l}\text { Long run } \\
\text { Earnings } \\
\end{array}$ & $\begin{array}{r}\text { Current Wage } \\
\text { Rate } \\
\end{array}$ & $\begin{array}{r}\text { Long run Wage } \\
\text { Rate } \\
\end{array}$ \\
\hline Current Earnings & $\begin{array}{r}0.029 \\
(3.62)\end{array}$ & & & \\
\hline Long run Earnings & & $\begin{array}{l}0.025 \\
(2.17)\end{array}$ & & \\
\hline $\begin{array}{l}\text { Current Wage } \\
\text { Rate }\end{array}$ & & & $\begin{array}{r}-0.0005 \\
(-0.05)\end{array}$ & \\
\hline $\begin{array}{l}\text { Long run Wage } \\
\text { Rate }\end{array}$ & & & & $\begin{array}{l}0.014 \\
(0.77)\end{array}$ \\
\hline Income of spouse & $\begin{array}{r}-0.064 \\
(-10.69)\end{array}$ & $\begin{array}{r}-0.078 \\
(-11.80)\end{array}$ & $\begin{array}{r}-0.069 \\
(-10.92)\end{array}$ & $\begin{array}{r}-0.077 \\
(-11.64)\end{array}$ \\
\hline $\begin{array}{l}\text { Mean Quality } \\
\text { Offer }\end{array}$ & $\begin{array}{l}-0.070 \\
(-1.43)\end{array}$ & $\begin{array}{l}-0.089 \\
(-1.70)\end{array}$ & $\begin{array}{l}-0.072 \\
(-1.43)\end{array}$ & $\begin{array}{l}-0.074 \\
(-1.42)\end{array}$ \\
\hline $\begin{array}{l}\text { County divorce } \\
\text { Rate }\end{array}$ & $\begin{array}{l}-0.003 \\
(-0.66)\end{array}$ & $\begin{array}{l}-0.003 \\
(-0.64)\end{array}$ & $\begin{array}{l}-0.003 \\
(-0.73)\end{array}$ & $\begin{array}{c}-0.002 \\
(-0.61)\end{array}$ \\
\hline AFDC Generosity & $\begin{array}{l}-0.151 \\
(-1.47)\end{array}$ & $\begin{array}{l}-0.184 \\
(-1.68)\end{array}$ & $\begin{array}{l}-0.128 \\
(-1.22)\end{array}$ & $\begin{array}{l}-0.168 \\
(-1.52)\end{array}$ \\
\hline Date of Marriage & $\begin{array}{l}-0.011 \\
(-4.98)\end{array}$ & $\begin{array}{l}-0.011 \\
(-4.66)\end{array}$ & $\begin{array}{l}-0.009 \\
(-4.12)\end{array}$ & $\begin{array}{l}-0.010 \\
(-4.52)\end{array}$ \\
\hline $\begin{array}{l}\text { Children under } 6 \\
\text { years old }\end{array}$ & $\begin{array}{r}-0.227 \\
(-1.08)\end{array}$ & $\begin{array}{r}-0.299 \\
(-1.34)\end{array}$ & $\begin{array}{l}-0.288 \\
(-1.31)\end{array}$ & $\begin{array}{l}-0.350 \\
(-1.55)\end{array}$ \\
\hline Pre-marital birth & $\begin{array}{l}0.670 \\
(2.84)\end{array}$ & $\begin{array}{l}0.720 \\
(2.87)\end{array}$ & $\begin{array}{l}0.718 \\
(2.90)\end{array}$ & $\begin{array}{l}0.732 \\
(2.88)\end{array}$ \\
\hline Any Birth & $\begin{array}{l}0.248 \\
(1.00)\end{array}$ & $\begin{array}{l}0.165 \\
(0.63)\end{array}$ & $\begin{array}{l}0.139 \\
(0.54)\end{array}$ & $\begin{array}{l}0.164 \\
(0.62)\end{array}$ \\
\hline Number of Births & $\begin{array}{r}-0.071 \\
(-0.69) \\
\end{array}$ & $\begin{array}{r}-0.129 \\
(-1.18) \\
\end{array}$ & $\begin{array}{l}-0.107 \\
(-1.00) \\
\end{array}$ & $\begin{array}{l}-0.127 \\
(-1.15) \\
\end{array}$ \\
\hline \# obs : & 9102 & 8317 & 8641 & 8207 \\
\hline
\end{tabular}

Notes
Additional included variables are a set of dummies for duration of marriage, the individual's normalised AFQT score, a measure of the individual's adherence to traditional gender roles, state dummies, number of children, and dummies for: whether the individual received AFDC, had a religious up-bringing, lived in an intact family at age 14, either parent was a high school drop-out, either parent worked full-time at age 14, has children under 6 years old, had a pre-marital birth, had any births. Long run wages and long run earnings are the individual's estimated fixed effect from a fixed effect regression for wage rates and earnings respectively (see Appendix Table 1). t-statistics in parentheses. 
Table A1: Estimation of Long-run Wages and Earnings: Women and Men

\begin{tabular}{|c|c|c|c|c|}
\hline & \multicolumn{2}{|c|}{ Earnings } & \multicolumn{2}{|c|}{ Wages } \\
\hline & Women & Men & Women & Men \\
\hline Work Experience & $\begin{array}{r}0.026 \\
(30.73)\end{array}$ & $\begin{array}{r}0.041 \\
(27.96)\end{array}$ & $\begin{array}{c}0.008 \\
(7.10)\end{array}$ & $\begin{array}{r}0.010 \\
(10.30)\end{array}$ \\
\hline Work Experience Squared/1000 & $\begin{array}{r}-0.024 \\
(18.05)\end{array}$ & $\begin{array}{r}-0.032 \\
(14.44)\end{array}$ & $\begin{array}{r}-5.9 \mathrm{e}-06 \\
(3.40)\end{array}$ & $\begin{array}{r}-9.5 e-06 \\
(5.80)\end{array}$ \\
\hline Urban location & $\begin{array}{l}0.540 \\
(3.66)\end{array}$ & $\begin{array}{c}0.834 \\
(2.95)\end{array}$ & $\begin{array}{r}0.510 \\
(2.70)\end{array}$ & $\begin{array}{l}0.290 \\
(1.40)\end{array}$ \\
\hline Local Unemployment Rate (t-1) & $\begin{array}{l}-0.019 \\
(1.47)\end{array}$ & $\begin{array}{l}-0.092 \\
(3.45)\end{array}$ & $\begin{array}{l}-0.003 \\
(0.20)\end{array}$ & $\begin{array}{r}-0.100 \\
(5.40)\end{array}$ \\
\hline Number of kids at $(\mathrm{t}-1)=1$ & $\begin{array}{r}-1.873 \\
(21.62)\end{array}$ & $\begin{array}{c}0.712 \\
(3.69)\end{array}$ & $\begin{array}{l}-0.710 \\
(6.30)\end{array}$ & $\begin{array}{l}0.300 \\
(2.20)\end{array}$ \\
\hline Number of kids at $(\mathrm{t}-1)=2,3$ & $\begin{array}{r}-1.343 \\
(14.84)\end{array}$ & $\begin{array}{r}0.441 \\
(2.03)\end{array}$ & $\begin{array}{l}-0.330 \\
(2.80)\end{array}$ & $\begin{array}{l}0.200 \\
(1.20)\end{array}$ \\
\hline Number of kids at $(\mathrm{t}-1)=4,5$ & $\begin{array}{l}-0.794 \\
(8.00)\end{array}$ & $\begin{array}{l}-0.037 \\
(0.14)\end{array}$ & $\begin{array}{l}-0.230 \\
(1.80)\end{array}$ & $\begin{array}{r}0.200 \\
(0.10)\end{array}$ \\
\hline Number of kids at (t-1) $\square 6$ & $\begin{array}{l}-0.925 \\
(7.91)\end{array}$ & $\begin{array}{l}-0.379 \\
(1.32)\end{array}$ & $\begin{array}{r}0.020 \\
(0.20)\end{array}$ & $\begin{array}{r}-0.200 \\
(0.80)\end{array}$ \\
\hline Intercept & $\begin{array}{r}5.435 \\
(27.64)\end{array}$ & $\begin{array}{r}9.340 \\
(24.01)\end{array}$ & $\begin{array}{r}3.700 \\
(14.40)\end{array}$ & $\begin{array}{r}6.300 \\
(21.80)\end{array}$ \\
\hline $\begin{array}{l}\text { \# obs } \\
\text { \# people }\end{array}$ & $\begin{array}{r}25416 \\
3172\end{array}$ & $\begin{array}{r}20475 \\
2707\end{array}$ & $\begin{array}{r}25109 \\
3172 \\
\end{array}$ & $\begin{array}{r}20297 \\
2708 \\
\end{array}$ \\
\hline
\end{tabular}

Notes

Estimates from fixed effects estimation. Work experience is the cumulative sum of weeks worked. $\mathrm{t}$-statistics in parentheses. 
Table A2: Hazard Rate Estimates of Time to Marriage and Time to Divorce, Women and Men.

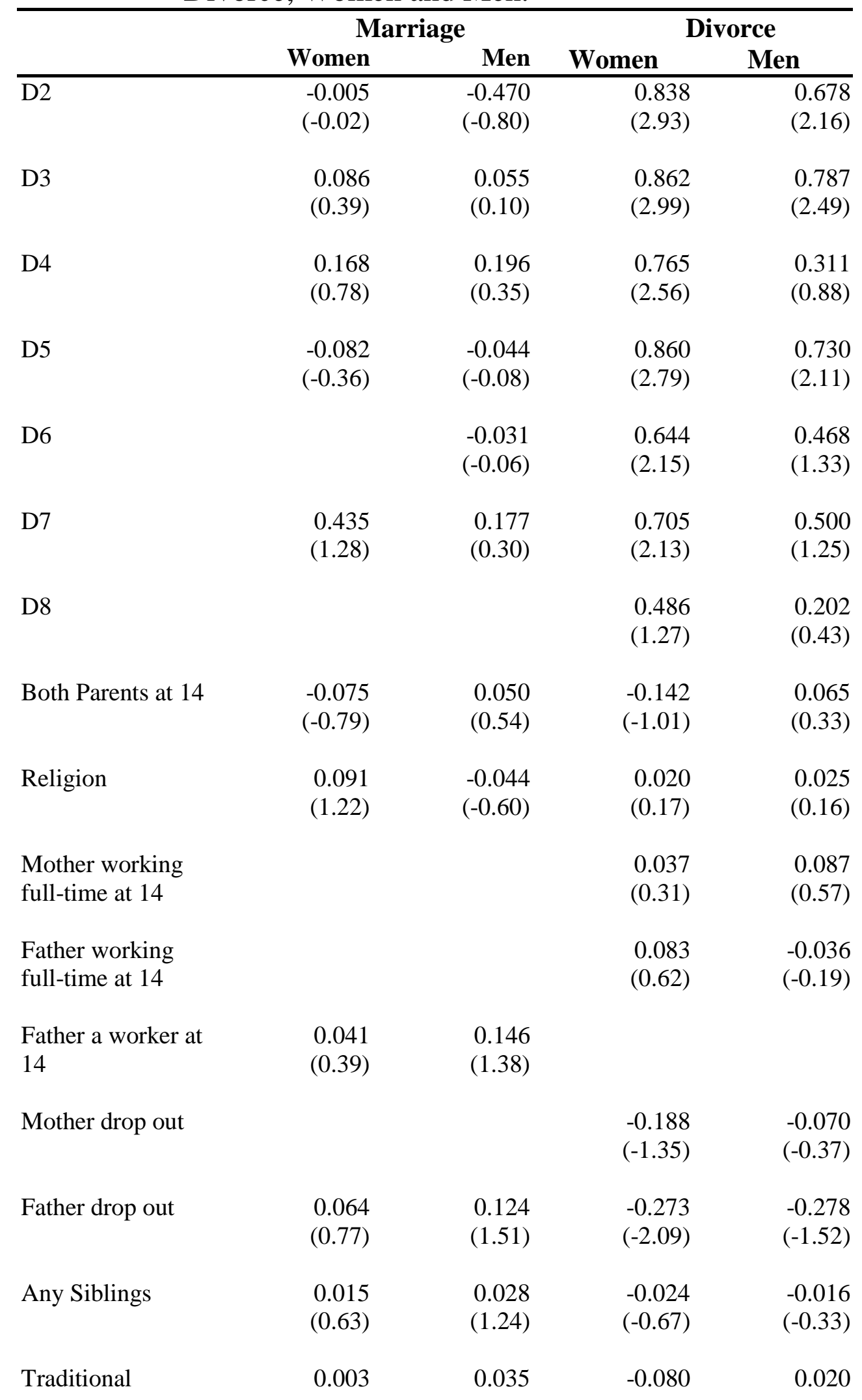




\begin{tabular}{|c|c|c|c|c|}
\hline Attitudes & $(0.14)$ & $(1.61)$ & $(-2.41)$ & $(0.45)$ \\
\hline $\begin{array}{l}\text { Family Income in } \\
1979\end{array}$ & $\begin{array}{l}-0.021 \\
(-1.76)\end{array}$ & $\begin{array}{l}-0.042 \\
(-3.25)\end{array}$ & $\begin{array}{r}-0.000002 \\
(-0.03)\end{array}$ & $\begin{array}{r}0.00002 \\
(-0.73)\end{array}$ \\
\hline $\begin{array}{l}\text { Family Income in } \\
1979^{*} \text { Age }\end{array}$ & $\begin{array}{l}0.001 \\
(1.75)\end{array}$ & $\begin{array}{c}0.002 \\
(3.10)\end{array}$ & & \\
\hline AFQT score & $\begin{array}{l}0.004 \\
(2.34)\end{array}$ & $\begin{array}{r}0.001 \\
(0.74)\end{array}$ & $\begin{array}{l}-0.003 \\
(-1.11)\end{array}$ & $\begin{array}{r}0.003 \\
(0.75)\end{array}$ \\
\hline Age at Marriage & & & $\begin{array}{l}-0.010 \\
(-4.52)\end{array}$ & $\begin{array}{l}-0.009 \\
(-3.09)\end{array}$ \\
\hline $\begin{array}{l}\text { Children under } 6 \\
\text { years old }\end{array}$ & & & $\begin{array}{l}-0.350 \\
(-1.55)\end{array}$ & $\begin{array}{l}-0.264 \\
(-0.83)\end{array}$ \\
\hline Pre-marital birth & & & $\begin{array}{r}0.732 \\
(2.88)\end{array}$ & $\begin{array}{l}0.726 \\
(2.02)\end{array}$ \\
\hline Any Births & & & $\begin{array}{l}0.164 \\
(0.62)\end{array}$ & $\begin{array}{r}0.210 \\
(0.57)\end{array}$ \\
\hline Number of Births & & & $\begin{array}{l}-0.127 \\
(-1.15)\end{array}$ & $\begin{array}{l}-0.051 \\
(-0.31)\end{array}$ \\
\hline $\begin{array}{l}\text { Mean Quality } \\
\text { Offer }\end{array}$ & $\begin{array}{l}-0.079 \\
(-2.11)\end{array}$ & $\begin{array}{l}-0.012 \\
(-0.61)\end{array}$ & $\begin{array}{l}-0.074 \\
(-1.42)\end{array}$ & $\begin{array}{r}-0.0002 \\
(-0.00)\end{array}$ \\
\hline $\begin{array}{l}\text { County divorce } \\
\text { rate }\end{array}$ & $\begin{array}{l}0.005 \\
(1.77)\end{array}$ & $\begin{array}{l}0.001 \\
(0.36)\end{array}$ & $\begin{array}{l}-0.002 \\
(-0.61)\end{array}$ & $\begin{array}{l}0.002 \\
(0.43)\end{array}$ \\
\hline AFDC Generosity & $\begin{array}{r}0.080 \\
(1.10)\end{array}$ & $\begin{array}{l}-0.022 \\
(-0.31)\end{array}$ & $\begin{array}{l}-0.168 \\
(-1.52)\end{array}$ & $\begin{array}{l}-0.092 \\
(-0.55)\end{array}$ \\
\hline AFDC Receipt & $\begin{array}{l}-0.108 \\
(-0.54)\end{array}$ & & & \\
\hline Income of spouse & & & $\begin{array}{r}-0.077 \\
(-11.64)\end{array}$ & $\begin{array}{l}-0.020 \\
(-2.08)\end{array}$ \\
\hline $\begin{array}{l}\text { Long run wage } \\
\text { Rate }\end{array}$ & $\begin{array}{l}-0.012 \\
(-0.92)\end{array}$ & $\begin{array}{r}0.030 \\
(3.35)\end{array}$ & $\begin{array}{l}0.014 \\
(0.77)\end{array}$ & $\begin{array}{l}-0.065 \\
(-2.58)\end{array}$ \\
\hline \# obs : & 5331 & 7265 & 8207 & 5447 \\
\hline
\end{tabular}




\begin{abstract}
Notes
Long run wages are the individual's estimated fixed effect from a fixed effect regression for wage rate.

Columns 1 and 2:

The dummies D\# are duration dummies, measured from age 13: D1 (which is omitted) represents "respondent aged less than 18"; D2 represents "respondent aged 18 or 19"; D3 represents "respondent aged 20, 21, 22, 23 or 24"; D4 represents "respondent aged 25 or 26"; D5 represents "respondent aged 27 or 28"; D6 represents "respondent aged 29 or 30"; D7 represents "respondent aged 31 or 32" and D8 represents "respondent aged 33 or 34".

Columns 3 and 4:

The dummies D\# are duration parameters, measured from the start of the marriage. D1 (which is omitted) represents "respondent married for between 0 and 1 years"; D2 represents "respondent married for between 1 and 2 years"; D3 represents "respondent married for between 2 and 3 years"; D4 represents "respondent married for between 3 and 4 years"; D5 represents "respondent married for between 4 and 5 years"; D6 represents "respondent married for between 5 and 7 years"; D7 represents "respondent married for between 7 and 9 years" and D8 represents "respondent married for between 9 and 14 years".

$\mathrm{t}$-statistics in parentheses.
\end{abstract}

